\title{
CONGENITAL MALFORMATIONS
}

\section{5}

TIIE EFFECT OF NIMODIPINE ON LEFT VENTRICULAR FUNCTION AND IIEMIODYNAMICS IN TIE NEWBORN LAMB. Marcel JU Albers, Erank yan, Bel, Roberl JMI Klaulz, Bai! Slecndijk, Jaap Ottenkang. Lan Baan. Dept. of Pediatrics and Cardiology, Univ. Hosp. Leiden, The Netherlands.

The calcium-channel blocker Nimodipine (Nimo) may mitigate birth asphyxia-induced brain damage. Many calcium-channel blockers negatively affect left ventricular function (contractility, cardiac output [CO]) and lower blood pressure. Nimo-treatment in asphyxiated newborns may be precluded because of the combination of poor posthypoxic hear function and cercbral autoregulation. In 8 vagotomized newbom lambs we investigated left ventricular (LV) function and systemic hemodynamics before and shortly after Nimo adininistration (20 ug/kg/iv). LV contractility and $\mathrm{CO}$ were assessed by measuring LV pressure (tip-manometer) and volume (conductance catheter), using
inferior caval vein occlusion lo obtain slope (Ees) and volume-intercept ( $V_{10}$ ) of the end-

sysiolic pressure-volume-relationship.
Results: LV-contractility decreased significanlly as shown by a docrease in Tes, but CO Results: LV-contractility decreased significandly as shown by a decrense in Tes, but $\mathrm{CO}$
did not significantly change. Mean blood pressure (MBl'), systemic vascular resistance did not significantly change. Mean blood
(SVR) and heart ratc (HR) decreased.

\begin{tabular}{|lccccc|}
\hline after vs before Nimo & Ecs & CO & MBP & SVR & HR \\
$\%$ change $\pm S D:$ & $-32 \pm 26^{*}$ & $-1.6 \pm 19.8$ & $-50 \pm 6^{*}$ & $-4.5 \pm 7^{*}$ & $-11 \pm 8$ \\
\hline
\end{tabular}

- $p<0.05$ (paired t-lcst)

Conclusion: Nimo affocts LV function and lowers blood pressure in the newborn liamb. Suggestien: Nimo should be used with caution in the aspliyxiated newborn, beciuse the combination of impaired cerebral autoregulation and suboptimal LV function with low systemic blood pressure may aggravate brain damage.

\section{6}

CONTROLLED CARDIAC REOXYGENATION REDUCES NITRIC OXIDE (NO) PRODUCTION AND OXIDANT INJURY OF HYPOXEMIC INFANT HEARTS. Michael P. Sherman, Gerald D. Buckberg, Kiyozo Mlorita, Kai Ihnken, and Louis J. Ignarro. Depts. of Pediatrics, Surgery, and Pharmacology. University of California, UCLA Medical Center, Los Angeles, California, U.S.A.

Cardiopulmonary bypass (CPB) is used increasingly to correct cyanotic heart defects during early infancy, but myocardial dysfunction is often seen after surgical repair. This study evaluates whether starting CPB at a conventional, hyperoxic $\mathrm{pO}_{2}$ causes an uninattended reoxygeration $\left(\mathrm{RcO}_{2}\right)$ injury. We subjected 2-week-old pigs to ventilator hypoxemia $\left[\mathrm{FIO}_{2}=0.06 \& \mathrm{pO}_{2}=25 \mathrm{mmHg}\right.$ followed by $5 \mathrm{~min}$ of $\mathrm{ReO}_{2}$ on CPB before instituting cardioplegia. CPB was begun in hypoxemic piglets by either abrupt $\mathrm{ReO}_{2}$ at a $\mathrm{pO}_{2}$ of $400 \mathrm{mmHg}$ [standard clinical practice] or by maintaining a $\mathrm{pO}_{2}=25 \mathrm{mmHg}$ on $\mathrm{CPB}$ until controlling $\mathrm{ReO}_{2}$ with blood cardioplegic arrest at a $\mathrm{BO}_{2}=400$. Myocardial NO production [chemiluminescence measurements of $\mathrm{NO}_{2}{ }^{-}+\mathrm{NO}_{3}-$ in aortic and coroniry sinus blooxl] ind conjugitted diene (CD) generation [spectrophotometric $A_{23}$ measurements of lipid extracis of blood] were assessed during cardioplegic induction. Thirty $\min$ after $C P B$, left ventricular end-systolic elastance [Ees, catheter conductance method] was used to determine cardiac function. CPB and blood cardioplegic arrest caused no functional or biochemical change in normoxic (control) versus hypoxemic heirts. Abrupt $\mathrm{ReO}_{2}$ caused a 10 -fold rise in NO and $C D$ production by the heart with subscquent depression of inyocardial function (Ees $=21 \pm 2 \%$ of control). In contrast, controlled cardiac $\mathrm{ReO}_{2}$ reduced NO production by $50 \%, \mathrm{CD}$ did not rise, and Ees was $83 \pm 8 \%$ of normal. We conclude controlled $\mathrm{ReO}_{2}$ when starting CPB to correct cyanotic heart defects may improve niyocardial status post-operatively.

MONITORING CARDIAC FUNCTION IN CIILDREN DURING AND AFTER DOXORUBICIN THERAPY. Cristina Azconi, Jesús Garcíil-Foncillas, Cirmen

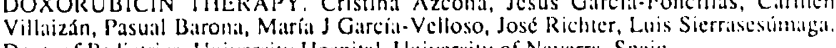
Dept. of Pediatrics. University llospitial. Universily of Navarria. Spatin.

In order to study doxorubucin cardiotoxicity in children affected of malignancies and treated with polychemolherapy without mediastinal radiotherapy, we have assesed cardiatc function in 59 children, mean age 16 years (range: 5 to 20 years; 33 males, 24 females) who have received a mean doxorubicin dosage of $340 \mathrm{mg} / \mathrm{m} 2$ (range: 123,5 to $800 \mathrm{mg} / \mathrm{m}^{2}$ ), performing serial radionuclide angiocardiographies (RNA) at rest atnd exercise during and after chemotherapy. The following parameters were studied by RNA: left ventricular ejection fraction (LVEF), LVEF in the first third of the cardiac cycle, as well as the emptying and lilling Maximal Rate (e/f-Max Rale), Averalge Ratte (e/f-Avg Rate) and Time to Peuk (e/f-T-P). 20 pattents have been followed afler completion therapy during a mean period of time of 13.6 months (range 3 in 26.4 months). Multivariate Cox model amblysis wits used to evaluate the doxorubicin cardioloxicity by RNA. At cumulative Jose ranging from 320 to $420 \mathrm{mg} / \mathrm{m}^{2}$ LVLF at $50 \%$ exercise and the emptying and filling Milx Ralte at $25 \%$ exercise decreased significamly $(p=0.041, p=0.0 .47$ resplectively). With doxorubicin dosige greatler than $420 \mathrm{mg} / \mathrm{m}^{2}$ we have found stitiscally signilicint differences in the following parameters: LVEF at rest, $25 \%$ and $50 \%$ excreise $(p=0.0301, p=0.028$ and $p=0.032)$. c/f-Max Rate at rest $(p=(0.0417, p=0.038)$ and $25 \%$ exercise $(p=(0.03 .3, p=0.045), \mathrm{e} / \mathrm{f}$.

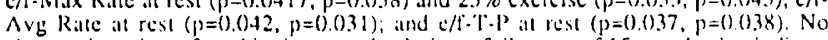
changes have been found in these results during a follow-up of 15 monilis that indicate inl improvement in ciordiace function.

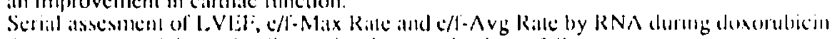

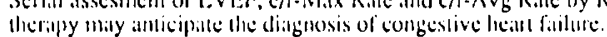

\section{8}

MAINZ CONGENITAL, BIRTM DEFECT MONITORING SYSTEM

Annette Queißer-Luft, Gabriela HaLck, Jürgen spranger

Department of PediatricB, Johannca-Cutenberg Univeroity, Mainz, BRD The two most important aimg of tho Mainz Congenital Birth Defect Monitoring Syotem were to find "incidence" rater and to look for et lological caunes of congenital malformatione. All bables born in Mainz underwent atandardized phyolcal and ponographic examination. Anamnestic data of family history, enviromental factors, drug exposure etc. were collected. Uoing case controll studies we looked for apecial correlationa between morphologic delocta and onamneatic ratio. Regubtei In 1990 and 1991 we oxaminatod 8430 newborna. 656 $(7,81)$ children had major and $2609(31,1)$ minor malformationa. syatemic localisation of major dofects: skeletal 2,61, urogenital systemic localisation of major dofocts: Skeletal 2,68, urogenital

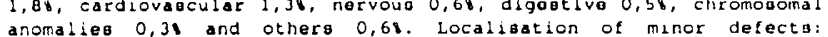
simian crease 3,98, Darwinian tubercle 3,88. facial haemangioma Simian crease 3,9l, Darwinian tubercle 3,89, facial haemangioma 3,21 , auricular tag 3,02 , haemangioma 2,71 , auricular pita 2,31 and
others 12,2\%. Increased relative riaks (odds ratiog) were found for following factorg: Sibing $\left(2,4^{*}\right) /$ parent $(1,4)$ with major
malformation, alcohol abuse $(2,3)$, medication $\left(1,8^{*}\right)$ during pregnaney, conaanguinity $(1,8)$, diabetes mellitus (mother; 1,7 ), placental insufficiency $(1,4)$ etc. (": statistically significant). Conclusions: The Mainz Congenital Birth Defect Monitoring Syotem is in the search for new etiological factors. Moro patients and a longer etudy perlod is necegary for in dopth evalution. Comparisono with other regional monitoring oystemg are required.

\section{9}

TERATOGENIC EFFECTS IN $A$ CASE OF MATERNAL TPEATMENT FOR ACUTE LYMPHOBLASTIC LEUKEMIA (ALL)

Andreas Artlicho, Jens Moller ${ }^{\circ}$, Alexander Tschakaloff", Eberhard Schwinger*, Klaus Kruse', Ludwig Gortner ${ }^{\circ}$

Depts. of "Maxillofacial Surgery, tlluman Genetics and - Paediatrics, Medizinische Universitat zu Lübeck, FRG Acute lymphoblastic leukaemia (ALL) was diagnosed in a 36 year-old and treated with cycarabin, daunorubicin, doxorubicin and cytarabin, thioguanin, respectively, in an unrecognized pregnancy at conception and at about 35-37 days p.c.. Amniocentesis at 16 weeks of gestation revealed a normal female karyotype.

At delivery, brachycephaly, hypoplasia of supraorbital bony structures and hypotelorism were seen. Hypoplastic nasal root, bilateral choanal atresia and micrognathia caused hypoplasia of naso- and oropharynx. There was also bilateral aplasia of the radius and hypoplasia of the first ray of the hands. Internally, an atrial septal defect II could be demonstrated. The malformations detected are in accord with the timing of teratogenesis. Neurodevelopment is normal at the age of 8 months. Experience with the use of cytotoxic drugs in pregnancy has so far been limited tc folate antagonists.

\section{DEVELOPMENTAL NEUROLOGY}

10

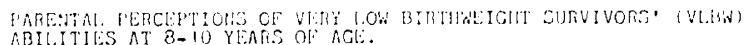
Caroline A Mackenzie and Rotert A Primhak [opn. by Prof M S Tanmer]. Department of Paediatrics. University of Sheftield, Shefrield. Ik.

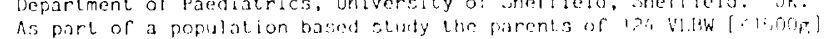

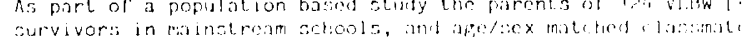
controls, were asked to assese thear chilutren's abilitues incliding aspects of school performance, and objective lest scores [BAs and TOMI $]$. There were significant differences in $10[p=<0.001]$, readirits

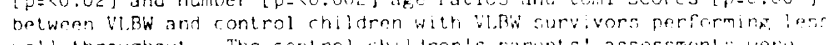
well throughoul. The control chlluren's partents' assessment:.: wore: not significantiy different to the teachers' but the Vibs children's

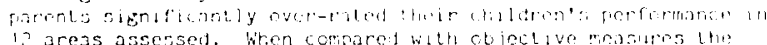
leachers or VLE'w and control children were equally accurate in their fredtction of overall school performance but the parents of l:He l'Lith children were signt ficanliy less accurate than the teachers, or cortro: children's parents. Interestingly however the VLa' parents had insight into their children's co-ordination tut not their children's parents over-estimate their children's abilities 